UDC 378.147:001.895:811.162.2

DOI https://doi.org/10.24919/2308-4863/35-4-36

Yevheniia MOSHTAGH, orcid.org/0000-0002-2174-8312

Candidate of Philological Sciences, Associate Professor at the Department of Foreign Languages O. M. Beketov National University of Urban Economy in Kharkiv (Kharkiv, Ukraine) evgeniyamoshtag@gmail.com

Maryna RYZHENKO, orcid.org/0000-0002-0961-3351 Candidate of Pedagogical Sciences, Associate Professor at the Department of Foreign Languages O. M. Beketov National University of Urban Economy in Kharkiv (Kharkiv,Ukraine) marina.ryzhenko.89@ukr.net

\title{
TRAINING OF FOREIGN LANGUAGE TEACHERS IN THE CONDITIONS OF DISTANCE EDUCATION
}

In the context of educational reforms in Ukraine that have taken place in recent decades and focus on increasing attention to education in general and training of future foreign language teachers in particular, it is important to refer to the historical experience of the past, study, analysis and generalization of which can be an important factor. improvement, finding effective ways to improve the training of teachers in modern conditions. Education is one of the important areas of society, on which its development largely depends. That is why the countries of the world have declared education the most important strategic area of socio-economic development. The current state of Ukraine is characterized by its desire to integrate into the European Community in economic, political and educational aspects. This requires the restructuring of the higher education system as a priority area for the formation of a new society, modernization of its content and improvement of the learning process based on the use of scientific approaches, the introduction of new technologies and more. Today, the development of technological means of telecommunications and communication, mass distribution and use of multimedia computer programs creates objective preconditions for the improvement of educational technologies, in particular, for the introduction of new forms of education for the general population, including distance learning. The need of modern society for specialists who are fluent in a foreign language in everyday life and in professional activities, necessitates the search for new constructive ideas to solve the problem of optimizing and intensifying foreign language learning, acquiring new knowledge and improving language and speech training.

Our article deals with the training of future teachers in the context of distance education. The rapid spread of COVID-19 in our country has led to the transition of universities to distance education. The effectiveness of teaching and learning in these conditions depends on the use of new methods and techniques that can compensate for the lively interaction of students and teachers and become an adequate alternative to sessions at the university. Thus, preparing future teachers for distance education requires the use of activities that enable students to acquire all types of speech skills and develop the ability to teach others. Thus, the relevance of the study lies in the need to create conditions for the training of future teachers in distance education.

Key words: distance education, student, teacher, modern learning technologies, professional activity, professional competence.

Свгенія МОШТАГ, orcid.org/0000-0002-2174-8312 кандидат філологічних наук, доиент кафедри іноземних мов Харківського національного університету міського господарства імені О. М. Бекетова (Харків, Украӥна) evgeniyamoshtag@gmail.com

Марина РИЖЕНКО, orcid.org/0000-0002-0961-335 кандидат педагогічних наук, доцент кафедри іноземних мов Харківського національного університету міського господарства імені О. М. Бекетова (Харків, Україна) marina.ryzhenko.89@ukr.net 


\section{ПІДГОТОВКА ВЧИТЕЛІВ ІНОЗЕМНОЇ МОВИ В УМОВАХ ДИСТАНЦІЙНОЇ ОСВІТИ}

У контексті освітніх реформ в Україні, які відбулися в останні десятиліття $і$ зосереджені на підвищенні уваги до освіти загалом і підготовки майбутніх учителів іноземних мов, важливо посилатися на історичний досвід минулого, вивчення, аналіз і узагальнення яких може бути важливим чинником удосконалення, пошук ефективних шляхів удосконалення підготовки вчителів у сучасних умовах. Освіта - одна з важливих сфер життя суспільства, від якої багато в чому залежить його розвиток. Ось чому краӥни світу проголосили освіту найважливішим стратегічним напрямом сочіально-економічного розвитку. Сучасний стан Украӥни характеризується ї̈ прагненням інтегруватися до Свропейського Союзу в економічному, політичному й освітньому аспектах. Це вимагає перебудови системи вищої освіти як пріоритетного напряму формування нового суспільства, модернізації ї̈ змісту та вдосконалення навчального процесу на основі використання наукових підходів, упровадження нових технологій тощя. Сьогодні розвиток технологічних засобів телекомунікацій та зв 'язку, масового розповсюдження та використання мультимедійних комп 'ютерних програм створює об' єктивні передумови для вдосконалення освітніх технологій, зокрема для впровадження нових форм навчання для широких верств населення, дистанційного навчання також. Потреба сучасного суспільства у спеціалістах, які вільно володіють іноземною мовою в повсякденному житті та професійній діяльності, зумовлює необхідність пошуку нових конструктивних ідей для вирімення проблеми оптимізаџії й активізаџії вивчення іноземних мов, набуття нових знань та вдосконалення мовної підготовки.

У нашій статті йдеться про підготовку майбутніх учителів у контексті дистанційної освіти. Швидке поширення COVID-19 у нашій краӥні призвело до переходу університетів на дистаниійну освіту. Ефективність викладання та навчання в иих умовах залежить від використання нових методів та прийомів, які можуть компенсувати жваву взаємодію студентів та викладачів, стати адекватною альтернативою сесіям в університеті. Отже, підготовка майбутніх учителів до дистаниійної освіти вимагає використання видів діяльності, які дають можливість учням набути мовленнєвих навичок усіх видів та розвинути здатність навчати інших. Актуальність дослідження полягає в необхідності створення умов для підготовки майбутніх учителів у дистанційній освіті.

Ключові слова: дистанційна освіта, студент, вчитель, сучасні технологї̈ навчання, професійна діяльність, професійна компетентність.

Formulation of the problem. Professional training of future foreign language teachers occupies one of the priority places in the system of higher pedagogical education. The attitude to mastering a foreign language as a secondary task is gradually changing, which provides only general cultural training for future professionals, because:

$-\mathrm{a}$ foreign language is an effective factor in humanizing education, as its use is associated with the process of interpersonal relationships. It is considered not only as a means of humanitarianization that affects the development of the personality of the person being taught, but also as a component of his professional training;

-it is impossible to express one's opinion correctly in a foreign language without being aware of the facts of reality, objects and phenomena in question. Thus, mastering a foreign language, its conscious use promotes the development of thinking;

- mastering a foreign language develops and logical thinking of the individual, because the language reflects the logic and systematic awareness of the material world;

- mastering a foreign language in higher education contributes to the development of future professionals the ability to correctly and competently convey their thoughts in their native language, prevents and helps to overcome professional integrity, the development of speech culture of the individual;
- with the help of a foreign language, future specialists get acquainted: with the culture, art of the country whose language they are studying, the works of its writers; with the way of life, customs, traditions, ethics of the people whose language they study; with universal values, which contributes to the development of the general culture of the individual;

- mastering a foreign language provides acquaintance with the culture of written communication;

- thanks to the knowledge of foreign languages, the graduate graduate obtains information about the development of his / her field of professional activity abroad, has the opportunity to compare the achievements of his / her country and his / her own with the achievements of colleagues abroad; participates in scientific and technical creativity, ensures compliance of the results of its work with the level of world standards;

- the importance for the future specialist of various skills in the field of foreign language is determined by the need to read and translate special literature, be able to study and systematize materials about professional activities, allows business correspondence in a foreign language, dialogue on business topics, etc.;

- gradually students develop the ability to work independently with foreign language professional information, which plays an important role in professional activities; 
- individualization during mastering foreign languages, formation of future specialists' ability to independently obtain the necessary knowledge, ability to apply and update them forces to rethink the process of training in general, select the most rational and acceptable methods, improve individual techniques.

The object of research is the process of training future teachers in the process of distance learning. The subject of the study is the process of training future teachers in distance education. The objectives of the study are as follows: 1) to analyze the nature and functions of distance learning; 2) formulate requirements for the organization of training of future teachers of English pronunciation in distance education; 3) identify trends in the development of professional training of future foreign language teachers in higher educational institutions of Ukraine in theory and practice in terms of distance learning.

Research analysis. The distance learning system in Ukraine is in its infancy. The means inherent in one or another form of learning are largely determined by what real opportunities a student and teacher have for interpersonal communication. For distance learning of foreign languages, this feature is the indirect indirect nature of the process of communication between teacher and student, which is carried out through computer communications. Distance learning provides the possibility of constant and dynamic telecommunication at a distance between student and teacher and students, and the initiative of such communication can come from any of these objects of the educational process. It is this feature that makes distance learning of foreign languages via the Internet significantly different in form from distance learning and to some extent bring it closer to full-time. It is clear that telecommunication communication is unable (for a number of psychological and pedagogical reasons) to completely replace direct "live" communication.

The purpose of the article. To carry out a holistic scientific analysis of the experience of professional training of future foreign language teachers in the system of distance learning and to substantiate possible ways of its introduction into the domestic educational and pedagogical space.

Modern living conditions require highly qualified specialists to achieve political and economic stability in the world. For a person capable of successful self-realization, the European educational space is characterized by increasing interest in learning foreign languages as a means of communication, expanding international relations, trying to establish new standards of relations between countries. As a result, there is a process of reforming and improv- ing the special training of foreign language teachers in both traditional and alternative forms of learning, such as distance learning. According to the outlined problem, its urgency, the basic concepts of research are "professional activity", "pedagogical activity", "professional competence of the teacher", "professional competence of the future teacher of a foreign language", "professional training of future teachers of a foreign language", "distance education" and "distance learning".

Issues of professional activity were studied by both domestic and foreign scientists: I. Bekh (definition of the personality of a professional in the context of its professional activity) (Бex, 1998: 4), A. Zhalinsky (in the context of defining the concept, essence, structural elements of professional activity), E. Klimov, A. Markov, E. Trifonov, G. Sukhodolsky, J. Richards, D. Raymond (the problem of professionalization). According to E. Trifonov, professional activity is a labor activity inherent in a professional, a high-level specialist who has a sufficient minimum of knowledge, skills, abilities for this activity to be effective (Безлюдна, 2017: 2). G. Sukhodolsky understood this term as a complex activity carried out by a person, a way of performing something that has a normatively established nature and requires long-term professional training (Безлюдна, 2015). The quality of pedagogical professional activity largely depends on the professional competence of the teacher. The problem of forming the professional competence of future teachers is covered in a number of thorough studies by V. Barkas, L. Beauty, A. Jones, L. Kalinina, A. Markova and others. V. Barkasi under the professional competence of the teacher understands the integral formation of personality, which includes a set of cognitive, technological, social, multicultural, autopsychological and personal components. The analysis of scientific research gave us grounds to outline the professional competence of a teacher as a set of values, knowledge, skills, abilities that determine the effectiveness of pedagogical activities, professional psychological knowledge, a set of professionally significant personal qualities and properties, unity of theoretical and practical readiness for professional pedagogical activity.

An important component of the training of foreign language teachers is foreign language communicative competence. General competencies are academic and empirical knowledge, skills, abilities, ability to learn, as well as existential competence, ie individual characteristics and personal qualities. Communicative speech (foreign language) competence consists of three components: linguistic (specific language knowledge and skills), sociolinguistic (determined by 
socio-cultural conditions of language use) and pragmatic (extralinguistic elements that provide communication).

According to the generalization of the components of foreign language communicative competence, common in understanding this concept is the ability and willingness of a non-native speaker to carry out effective foreign language communication, which is formed on the basis of a certain set of knowledge, skills and abilities. Thus, the foreign language communicative competence of the future foreign language teacher is an integrative creation of personality, which has a complex structure and is the interaction and interpenetration of linguistic, speech, sociocultural and intersocial components, the degree of formation of which allows future teachers to effectively) communication. Thus, the content of foreign language communicative competence described above determines the subject specialization of the professional competence of a foreign language teacher. In general, the professional competence of a foreign language teacher can be qualified as a set of general pedagogical, general cultural and foreign language communicative (linguistic, speech, sociolinguistic, pragmatic, sociocultural, social, strategic, discursive, subject) competencies of a specialist their professional activities aimed at teaching students intercultural communication in a foreign language. We also understand the structure and definition of professional competence of a foreign language teacher as a result of his training in the distance learning system.

The next initial concept of the research is "professional training of future foreign language teachers". At the present stage it is provided by the formation of the future teacher's personality, who consciously and motivatedly acquires special knowledge, skills and abilities, basics of skills in the professional field, as well as readiness for interethnic and intercultural cooperation, ability to solve professional and life problems in global space. Along with the traditional practice of foreign language teacher training both abroad and in our country, distance education is being actively introduced under the influence of scientific and technological progress. Such training has its own specifics and characteristics. Many domestic and foreign scientists work in the field of theory and practice of distance education, each of which has made a significant contribution to the popularization and implementation of pedagogical ideas of distance education, the organization of relevant research. Among them: D. Daniel, D. Keegan, V. Kukharenko, R. Melton, M. Moore, V. Oliynyk, B. Holmberg, B. Shunevych and others. M. Moore in the work "Distance Education: System Representation" by the method of litera- ture review explores the theory of distance education and gives everyone who deals with the problems of distance education, "learn what is known before they start looking for something new".

The term "distance education" is not yet stable in both Ukrainian and English-language scientific pedagogical literature. Studies on the problems of distance education provide numerous definitions of it, which generally differ from each other. This, on the one hand, is a sign of the versatility and scale of this phenomenon, and on the other - indicates that the subject and object of distance education, its conceptual apparatus has not yet been definitively defined. As D. Shele notes, "distance education is an ornament with an impressive paradox - it has defended its existence, but cannot define itself. We hold the position that the term "distance learning" means such an organization of the educational process, when the student is mainly, and often completely separated from the teacher in space or time, and the teacher develops a curriculum based mainly on independent student learning. This feature of education is characterized by the fact that the student and teacher have the opportunity to dialogue with each other through telecommunications. Distance learning provides an opportunity for residents of regions where there are no other opportunities for training or obtaining quality higher education, there is no university of the required profile or teachers of the required level of qualification. Distance learning is based on general didactic and specific principles, namely: humanization, scientificity, systematicity, individualization, openness and flexibility, expediency, mobility, interactivity (Гарбуза, 2015: 6).

In accordance with the above definitions and principles, the following characteristic features of distance learning can be distinguished:

- the basis of education is purposeful and controlled by teachers and organizers of education intensive independent work of students;

- subjects of study have the opportunity to carry out joint educational activities in a convenient place, according to a pre-agreed form and individual integrated schedule of interaction over time;

- distance learning process takes place in a special pedagogical system, the components of which are subsystems: goals, content, technologies, tools, organizational forms of learning (identification-control, educational-material, financial-economic, normativelegal, marketing);

- the presence of information and educational environment as a systemically organized set of traditional and computer-based learning tools, where there is dialogue and data transmission, interaction proto- 
cols, a system of multimedia, information and telecommunications technologies, information resources, system hardware and software, focused on meeting the educational needs of distance learning users.

Based on these characteristics of distance learning, define its properties:

- flexibility and adaptability (those who study, work in a convenient mode (place of study, pace of work), which provides great benefits for those who can not or do not want to break the usual rhythm of his active social life);

- modularity (distance learning programs are based on the modular principle, where each individual course creates a holistic view of a particular subject area. This allows the list of independent courses modules - to form a curriculum that meets individual or group needs);

- a new role of the teacher as a coordinator of the cognitive process, adjusting the course being taught, a consultant in drawing up an individual curriculum, a project manager who checks current tasks, etc. (he leads mutual support study groups, helps students in their professional self-determination). The peculiarity of distance learning helps to improve the training, retraining and advanced training of teachers, psychologists and tutors who accompany the learning process, and therefore must have modern knowledge of the subject, have methods and tools for organizing and conducting distance learning. Distance learning uses special technologies and tools, including common case technologies (based on training materials for self-study and control tasks and tests for self-control), television technologies (based on closed-loop television feedback systems), video conferencing technologies (based on the means of providing twoway or multilateral audio and video communication over long distances), computer and telecommunications technologies ("client-server" technologies based on the widespread use of computer and telecommunications equipment), combined technologies (combination of two or more than the previous ones). From the pedagogical point of view, distance learning technologies practically integrate most of the existing teaching methods and provide them with a qualitatively new, higher educational and technological level. The defining component of distance learning technologies are the tools used in distance education - traditional, computer-oriented, information (Амеліна, Гаманюк, 2013: 1). Naturally, these teaching aids embody the latest achievements of world science and technology. In addition, combinations of tools that are much more common than in traditional educational technologies are actively used. Distance learning tools include printed publications, electronic publications on flexible magnetic, laser or hard disks, computer training systems in regular and multimedia versions, audio and video training and information materials, laboratory distance workshops, simulators, databases with remote access, electronic libraries with remote access, didactic materials based on expert and geographic information training systems, computer networks, television programs, etc. The leading link in distance learning is the means of telecommunications and their transport base. They are used to provide the educational process with the necessary teaching materials; feedback between the teacher and the learners; exchange of management information within the distance learning system; access to international information networks, as well as to connect to the distance education system of a wide range of users, including foreign ones (Лісова, 2015: 8). Technologies and means of distance learning together with methods form a unique distributed information environment, which determines the main features, advantages and problems of this promising form of education. The most important role in the process of distance learning is played by blogs on social networks, such as: Viber, Telegram, WhatsApp, etc. Of course, it should be noted that social networks can only help teachers and students achieve their learning goals. It can be emphasized that there are platforms for distance learning, such as Microsoft Teams and Zoom. These platforms greatly simplify the learning process in quarantine. Using special applications, you can fully conduct lectures in the form of video conferences and practical classes using modern distance learning tools.

Modern students need a special approach and highly qualified specialists in the field of modern education, which would encourage the modern young generation to learn foreign languages and love to learn. The use of digital resources helps students to study at universities, stimulates their thinking, provides new opportunities and allows them to learn to discover new talents. Foreign language teachers who work with modern students are aware that such students think they are behaving differently than previous generations. Most distance learning programs allow students to work in their own place and in their spare time. With more flexibility comes more responsibility on the part of the student. Students must learn to work well on their own and without the constant guidance and monitoring of an instructor, making distance learning a challenge for those who are not easily motivated. Not everyone can qualify for a distance learning program. Successful participants must be highly motivated and self-disciplined. Because the course may be out of control, students themselves have full 
responsibility for continuing the course and assessing their skill in the skill or subject. In virtual communication, the teacher or professor must certainly take into account the specifics of linguistic tools and resources, the rules of interaction, through technological features that can not only promote dialogue, but also complicate it. Teachers are faced with both methodological and didactic tasks aimed at optimizing the communication process, which is determined by the ability to dialogue with interlocutors, formulate their opinions, define tasks, avoid ambiguity of messages, etc.

One of the most important functions performed by the teacher is the function of control - to test the knowledge, competencies and skills of the studied subject, which students receive both in class and outside it. For this purpose, distance learning courses using various forms, types and methods of control have been created. Control over the educational and cognitive activities of students in advanced distance learning courses is aimed at both teacher control and student self-control. External feedback is provided by implementing a number of factors: 1) control functions; 2) types of control; 3) methods of control; 4) forms of control. During distance learning of a foreign language, control is implemented by the following functions: 1) testing function, which shows the results and assessment of student learning; 2) educational function, which comes by means of recollection, consolidation, clarification, updating of acquired knowledge; 3) the developmental function plays a major role in the development of the student's personality, his cognitive abilities, concentration, memory, thinking, imagination; 4) formative function, the essence of which is to discipline the work of students, increase a sense of responsibility for their work, stimulating a serious attitude to it. Usually the types of control can be distinguished by temporal features: diagnostic, current, periodic and final. Diagnostic control during distance learning of foreign languages is carried out with the help of "placement tests", which allows to determine the initial level of preparation of students in order to study the allowable complexity of the proposed educational content. Analysis of pre-control data also allows the teacher to make changes to distance learning courses with an emphasis on the student's knowledge of a foreign language. Current control allows you to have constant information about the progress and quality of learning material, to make changes in the learning process in a timely manner. The current control in advanced distance learning courses is not so much an inspection as an education, as it involves the consolidation, review and analysis of educational material. Periodic control allows you to determine the quality of students' study material in this subject. It takes the form of term tests or end-of-term credits for courses whose final test is an exam. The final control is used to reflect the final results of the educational process in this subject. Methods of control allow to determine the progress in the educational and cognitive activities of students, as well as the pedagogical work of the teacher. Testing knowledge during distance learning is a very special process and requires special attention, teacher knowledge and special skills. For example, during e-learning of a foreign language in the developed courses the following basic methods of control are used:

- reading, translation of the text and performance of tasks to it;

- listening and performing tasks after listening to the text;

- grammar tasks;

- talking on a certain topic.

The exchange of information between the student and the teacher takes place by electronic means, via Skype or by mail. Work with all tasks should be limited in time, so for control the student must agree on the time and date of the beginning and end of the test for proper control (Воронкін, 2016: 5).

Conclusions. The use of distance education in the teaching of a foreign language is a major breakthrough in the education of students who do not have the opportunity to be present in classrooms for good reasons and gain knowledge in the traditional way. The paper reveals that with the help of the most modern tools for synchronous and asynchronous communication, the distance learning system will be able to work in a constant normal rhythm. Thus, the distance or distance learning process is carried out using a combination of synchronous and asynchronous tools, while maintaining flexibility and convenience and expanding the quality and efficiency of both methods of communication. Applying a combination of pedagogical knowledge and modern technologies, it is possible to implement a successful distance learning course in a foreign language. The outlined tasks of the work are to show the effectiveness of e-learning and compare it with the traditional form of language learning. In the age of high technology in the world, the use of distance learning through electronic devices, the Internet, computers in the learning process is growing, and we must synchronize the traditional way with it and increase our ability to work with technology to expand knowledge. More and more teachers and students are getting acquainted with technologies, using them and incorporating them into their learning style, and these technologies provide practical and creative ideas and force them to create their own modern teaching methods. 


\section{BIBLIOGRAPHY}

1. Амеліна С., Гаманюк В. Впровадження європейських освітніх стандартів у систему іншомовної освіти України. Актуальні проблеми філологї̈ і методики викладання мов : збірник наукових праць. Кривий Ріг, 2013. Вип. 9. C. $162-171$.

2. Безлюдна В. Організація педагогічної практики у вищій школі як фактор розвитку професійної компетенції майбутніх учителів іноземних мов. Науковий вісник Мелітопольського державного педагогічного університету. Серія «Педагогіка». 2017. № 1 (18). С. 106-112.

3. Безлюдна В. Основні види інноваційних технологій в процесі вивчення іноземних мов. Інноваційний розвиток вищзӧ освіти : глобальний та національний виміри змін : матеріали II Міжнародної науково-практичної конференції, 26-27 березня 2015 р., м. Суми. Суми : Вид-во СумДПУ імені А. С. Макаренка, 2015. Т. 2. С. $23-25$.

4. Бех І. Особистісно зорієнтоване виховання : навчально-методичний посібник. Київ : ІСДО, 1998. С. 204.

5. Воронкін О. Тенденції розвитку інформаційно-комунікаційних технологій навчання студентів вищих навчальних закладів України (друга половина XX - початок XXI ст.) : дис. канд. ... пед. наук: 13.00.10. Старобільськ, 2016. $497 \mathrm{c}$.

6. Гарбуза Т. Професійна підготовка майбутніх учителів іноземної мови в системі дистанційного навчання університетів Великої Британії : дис. ... канд. пед. наук: 13.00.04. Київ, 2015. 236 с

7. Lisova S. The problem of ensuring the quality of higher education from the standpoint of a systematic approach. Professional pedagogical education : system research : monograph / ed. O. Dubaseniuk. Zhytomyr : ZhSU Publishing House I. Franko, 2015. P. $160-172.238$ p.

8. Lichman L. Transformation of scientific and practical experience in implementing the ideas of foreign language competence in the modernization of the education system in Ukraine (1991-2000). New pedagogical thought. 2016. № 2. P. 53-56.

\section{REFERENCES}

1. Amelina S. M., Hamanyuk V. A. Vprovadzhennya yevropeys'kykh osvitnikh standartiv u systemu inshomovnoyi osvity Ukrayiny. Aktual'ni problemy 388 filolohiyi i metodyky vykladannya mov: zbirnyk naukovykh prats'. [Implementation of European educational standards in the system of foreign language education in Ukraine. Current issues 388 philology and methods of language teaching: a collection of scientific papers. Vyp. 9. Kryvyy Rih, 2013. pp. 162-171. [in Ukrainian]

2. Bezlyudna V. V. Orhanizatsiya pedahohichnoyi praktyky u vyshchiy shkoli yak faktor rozvytku profesiynoyi kompetentsiyi maybutnikh uchyteliv inozemnykh mov. [Organization of pedagogical practice in higher school as a factor in the development of professional competence of future foreign language teachers]. Scientific Bulletin of Melitopol State Pedagogical University 2017. № 1 (18). pp. 106-112. (Seriya: Pedahohika). [ in Ukrainian].

3. Bezlyudna V. V. Osnovni vydy innovatsiynykh tekhnolohiy v protsesi vyvchennya inozemnykh mov. Innovatsiynyy rozvytok vyshchoyi osvity : hlobal'nyy ta natsional'nyy vymiry zmin: materialy II Mizhnarodnoyi naukovo-praktychnoyi konferentsiyi (26-27 bereznya 2015 roku, m. Sumy). T. 2. Sumy: Vyd-vo SumDPU imeni A. S. Makarenka, [The main types of innovative technologies in the process of learning foreign languages. Innovative development of higher education: global and national dimensions of change: materials of the II International scientific-practical conference] 2015. pp. 23-25. [in Ukrainian].

4. Bekh I. D. Osobystisno zoriyentovane vykhovannya : navch.-metod. posib. K.: ISDO, [Personally oriented education: teaching method. way. K.: ISDO, 1998. C. 204],1998. p. 204 [in Ukrainian].

5. Voronkin O. S. Tendentsiyi rozvytku informatsiyno-komunikatsiynykh tekhnolohiy navchannya studentiv vyshchykh navchal'nykh zakladiv Ukrayiny (druha polovyna XX - pochatok XXI stolittya): dys. kand. ... ped. nauk: 13.00.10. Starobil's'k, [Tendencies of development of information and communication technologies of training of students of higher educational institutions of Ukraine (second half of XX - the beginning of XXI century): dis. cand. ... ped. science: 13.00 .10 . Starobilsk, 2016. 497 p.], 2016. P. 497 [in Ukrainian].

6. Harbuza T. V. Profesiyna pidhotovka maybutnikh uchyteliv inozemnoyi movy v systemi dystantsiynoho navchannya universytetiv Velykoyi Brytaniyi: dys. ... kand. ped. nauk: 13.00.04. [Professional training of future foreign language teachers in the system of distance learning of universities in Great Britain: dis. ... cand. ped. science: 13.00.04. K., 2015. 236 p.] K., p. 236 [in Ukrainian].

7. Lisova S. V. Problema zabezpechennya yakosti vyshchoyi osvity z pozytsiy systemnoho pidkhodu. [The problem of ensuring the quality of higher education from the standpoint of a systematic approach.] Professional pedagogical education: system research: monograph / ed. OA Dubaseniuk. Zhytomyr: ZhSU Publishing House. I. Franko, 2015. Profesiyna pedahohichna osvita: systemni doslidzhennya: monohrafiya / za red. O. A. Dubasenyuk. Zhytomyr: Vyd-vo ZHDU im. I. Franka, 2015. pp. $160-172.238$. [in Ukrainian].

8. Lichman L. Transformatsiya naukovo-praktychnoho dosvidu vprovadzhennya idey inshomovnoyi kompetentnosti v umovakh modernizatsiyi systemy osvity v Ukrayini [Transformation of scientific and practical experience in implementing the ideas of foreign language competence in the modernization of the education system in Ukraine] 1991-2000. Nova pedahohichna dumka. 2016. № 2. pp. 53-56. [in English]. 